\title{
Effects of dietary fibre source and enzyme supplementation on faecal apparent digestibility, short chain fatty acid production and activity of bacterial enzymes in the gut of piglets
}

\author{
M.S.C. Carneiro, M.M. Lordelo, L.F. Cunha, J.P.B. Freire* \\ Universidade Técnica de Lisboa, Instituto Superior de Agronomia, \\ Tapada da Ajuda, 1349-017 Lisboa, Portugal
}

Received 28 November 2006; received in revised form 5 December 2007; accepted 7 December 2007

\begin{abstract}
The effects of fibre source, either wheat bran (WB) or maize cobs (MC), and dietary exogenous enzymes (ES) on performance and digestive parameters of weaned piglets were studied in 24 Duroc $\times$ Landrace male piglets, weaned at 21 days of age. There were four treatments arranged factorially, with two sources of fibre (WB or MC) and two concentrations of ES $(0$ or $0.15 \mathrm{~g} / \mathrm{kg})$ that contained $800 \mathrm{U} / \mathrm{kg}$ of endo-1,4- $\beta$-cellulase, $1800 \mathrm{U} / \mathrm{kg}$ of endo-1,3(4)- $\beta$-D-glucanase and $2600 \mathrm{U} / \mathrm{kg}$ of endo-1,4- $\beta$-xylanase. The digestibility of the neutral detergent fibre was higher $(\mathrm{P}<0.001)$ in diets containing WB and the digestibility of the acid detergent fibre increased with ES. Small intestine digesta contents $(\mathrm{g} / \mathrm{kg}$ live weight) at slaughter were higher $(\mathrm{P}<0.01)$ in pigs fed $\mathrm{MC}$ than in pigs fed WB. Fibre source did not affect the amounts $(\mathrm{mmol} / \mathrm{l})$ of short chain fatty acids (SCFA) in the small intestine. However, replacement of WB by MC increased acetic acid and decreased butyric acid concentrations $(\mathrm{P}<0.05)$ in the caecum. In addition, pigs fed diets with $\mathrm{MC}$ as the major fibre source had lower $(\mathrm{P}<0.05)$ concentration of butyric acid in the colon than pigs fed diets with WB. Enzyme supplementation affected molar proportions of SCFA formed in the small intestine and tended to
\end{abstract}

Abbreviations: ADF, acid detergent fibre; BW, body weight; CP, crude protein; DM, dry matter; ES, enzyme complex supplement; GIT, gastrointestinal tract; MC, maize cobs; N, nitrogen; NDF, neutral detergent fibre; NSP, non-starch polysaccharide; SCFA, short chain fatty acids; SI, small intestine; TTAD, total tract apparent digestibility; WB, wheat bran.

* Corresponding author. Tel.: +35121 3653408; fax: +351213630734.

E-mail address: jpfreire@ isa.utl.pt (J.P.B. Freire). 
increase acetic acid, propionic acid and total SCFA concentrations in the colon of piglets fed WB $(\mathrm{P}<0.10)$. The xylanolytic and cellulolytic activities in the caecum and colon were higher $(\mathrm{P}<0.05)$ for piglets fed WB than for piglets fed MC. In conclusion, ES increased the digestibility of acid detergent fibre and neutral detergent fibre and the replacement of WB by MC reduced neutral detergent fibre and acid detergent fibre digestibility, caecal butyric acid production and hindgut activity of bacterial enzymes.

(C) 2007 Elsevier B.V. All rights reserved.

Keywords: Piglets; Dietary fibre; Enzymes; Intestinal fermentations

\section{Introduction}

Non-starch polysaccharides (NSP) present in diets for weaning pigs might improve health by modifying gastrointestinal tract (GIT) motility, transit time of digesta or by the production of beneficial fermentation products. Several studies have shown that dietary fibre influences digestive secretion rates by increasing the activity of pancreatic enzymes (Corring et al., 1989), the concentration of intestinal enzymes (Lizardo et al., 1997) and also the release of mucin (Montagne et al., 2003).

The addition of enzymes such as xylanase, $\beta$-glucanase, and cellulase to fibre-rich diets may improve NSP digestibility. However, published responses to enzyme supplementation (ES) in piglet diets are not always consistent and thus deserve further investigation ( $\mathrm{Li}$ et al., 1996; Baidoo et al., 1998; Gill et al., 2000).

Wheat bran (WB) is a traditional source of NSP for piglets and it is rich in arabinoxylans, cellulose and $\beta$-glucans (Bach Knudsen, 2001). However, total tract apparent digestibility (TTAD) of neutral detergent fibre (NDF) and acid detergent fibre (ADF) might be lower for WB based diets than for diets which contain more soluble fibre sources such as sugar beet pulp or soybean hulls (Freire et al., 2000). Maize cobs (MC) are a waste by-product of the maize industry that could be used as an economical alternative to other fibre sources in pig diets. Maize cobs have a similar amount of arabinose to WB but a considerably higher amount of xylose (Chabeauti et al., 1991; Pellerin et al., 1991). On the other hand, WB is relatively more digestible than $\mathrm{MC}$ as it contains lower amounts of cellulose and lignin per unit of NDF. Moreover, WB has more starch and protein (CP), two dietary components that are more easily digested by the pig than fibre. However, there is little information on the TTAD of NSP of MC and how this fibre source might affect gut fermentation in the young pig.

Dietary fibre sources affect the microbial fermentative process in the GIT of pigs namely microbial diversity, end products of microbial fermentation and microbial enzyme activity. The caveat of studying microbial diversity is that cell culture techniques are time consuming and only provide information on bacteria that can be cultured (Bach Knudsen et al., 1991; Wang et al., 2004). Also, alternative molecular approaches are expensive and require specialized equipment (Konstantinov et al., 2004). In contrast, the concentrations of the main end products of microbial fermentation, such as short chain fatty acids (SCFA) are easy to determine and correlate directly to microbial growth which is determined by the ATP concentration measured on the digestive contents and activity in the GIT (Bach Knudsen et al., 1991). In addition, bacterial enzyme activities are also associated with microbial 
activity in the GIT and therefore can be used as an additional tool to better understand the microbial fermentative process. Thus, measuring the end products of microbial fermentation and microbial enzyme activity might be an effective method to assess changes in the fermentative process when different fibre sources are included in pig diets.

The present work examines the effect of replacing wheat bran by maize cobs and adding an enzyme complex to the diet on the total tract apparent digestibility, nitrogen balance and short chain fatty acids as end products of the fermentative digestion in the gut contents of pigs after weaning.

\section{Materials and methods}

\subsection{Pigs and diets}

Twenty-four Duroc $\times$ Landrace male piglets, weaned at $21 \pm 1.6$ days of age were used. The pigs were assigned into six blocks of four piglets each according to body weight (BW). Treatments were arranged factorially with two sources of fibre (WB or MC) and two amounts of an enzyme complex $(0$ or $0.15 \mathrm{~g} / \mathrm{kg}$ ) that contained $800 \mathrm{U} / \mathrm{kg}$ of endo- $1,4-\beta$ cellulase, $1800 \mathrm{U} / \mathrm{kg}$ of endo-1,3(4)- $\beta$-D-glucanase and $2600 \mathrm{U} / \mathrm{kg}$ of endo-1,4- $\beta$-xylanase. The enzyme product was Roxazyme (DSM Nutritional Products, Basel, Switzerland), which is derived from Trichoderma longibrachiatum. One unit of cellulase, glucanase and xylanase activity is defined as the amount of enzyme that releases $0.1 \mu$ mole of glucose per minute from carboxymethylcellulose, barley $\beta$-glucans and oat xylans, respectively at $\mathrm{pH} 5.0$ and $40^{\circ} \mathrm{C}$. Diets were balanced in amino acid concentration and had similar NDF content (Table 1). The chemical composition of WB and MC are presented in Table 2.

The piglets were individually placed in metabolic cages and had free access to water and feed. The feed was presented as $3 \mathrm{~mm}$ diameter pellets. Piglets were fed their respective experimental diets at day 1 and after a 7-day adaptation period faeces and urine were collected daily from each piglet from day 8 to day 12 and from day 15 to day 19. From 21 to 42 days of age, feed intake was monitored daily and BW gain was monitored weekly. At the end of the experiment, pigs were sedated and then slaughtered with a sodium thiopental overdose, after a $16 \mathrm{~h}$ fasting period. The digesta of the small intestine (SI), caecum and colon were removed immediately and the $\mathrm{pH}$ and dry matter (DM) determined for each. The contents were immediately frozen at $-20^{\circ} \mathrm{C}$ for future determination of SCFA and fermentative activity. All animal procedures were approved by the Portuguese Guidelines for the Protection of Animals Used in Experimental Research and other Scientific Purposes.

\subsection{Laboratory analysis}

Samples of faeces and diets were freeze-dried and ground in a laboratory hammer mill (Retsch 5657, Haan, Germany) through a $1 \mathrm{~mm}$ mesh screen.

Urine was continuously collected and removed from the container daily. Fifty millilitres sulphuric acid (5 vol.\%) was added to the container to prevent nitrogen (N) loss and the urine was then frozen at $-20^{\circ} \mathrm{C}$. On day 12 and day 19 , a representative sample of faeces and urine from each collection period was taken for future $\mathrm{N}$ analysis. 
Table 1

Composition and calculated and determined analysis of the experimental diets ( $\mathrm{g} / \mathrm{kg}$ as fed basis)

\begin{tabular}{|c|c|c|}
\hline Item & Diet 1 and $2^{\mathrm{a}}$, wheat bran & Diet 3 and $4^{\mathrm{a}}$, maize cob \\
\hline \multicolumn{3}{|l|}{ Ingredient } \\
\hline Wheat & 484.0 & 480.5 \\
\hline Maize starch & - & 60.0 \\
\hline Wheat bran & 150.0 & - \\
\hline Maize cob & - & 90.0 \\
\hline Soybean meal (480 g/kg CP) & 200.0 & 200.0 \\
\hline Fish meal $(700 \mathrm{~g} / \mathrm{kg} \mathrm{CP})$ & 60.0 & 60.0 \\
\hline Soybean oil & 70.0 & 70.0 \\
\hline L-Lysine & 4.0 & 5.0 \\
\hline DL-Methionine & 1.0 & 2.0 \\
\hline L-Threonine & 1.0 & 2.0 \\
\hline L-Tryptophane & - & 0.5 \\
\hline Calcium carbonate & 10.0 & 10.0 \\
\hline Dicalcium phosphate & 5.0 & 5.0 \\
\hline Sodium chloride & 5.0 & 5.0 \\
\hline Vitamin and trace mineral $\operatorname{mix}^{\mathrm{b}}$ & 10.0 & 10.0 \\
\hline \multicolumn{3}{|l|}{ Calculated chemical composition } \\
\hline Lysine $^{c}$ & 14.5 & 14.4 \\
\hline Methinonine $e^{c}$ & 5.3 & 5.9 \\
\hline Threonine $^{c}$ & 8.7 & 8.9 \\
\hline Tryptophane $^{c}$ & 2.6 & 2.7 \\
\hline Starch $^{\mathrm{d}}$ & 321.2 & 349.0 \\
\hline Net energy $(\mathrm{MJ} / \mathrm{kg})^{\mathrm{e}}$ & 11.38 & 11.51 \\
\hline \multicolumn{3}{|l|}{ Determined chemical composition } \\
\hline Dry matter & 906.9 & 912.7 \\
\hline Total ash & 53.8 & 56.5 \\
\hline Crude protein $(\mathrm{N} \times 6.25)$ & 181.1 & 177.9 \\
\hline Neutral detergent fibre & 133.6 & 134.1 \\
\hline Acid detergent fibre & 38.4 & 55.4 \\
\hline Acid detergent lignin & 9.0 & 10.5 \\
\hline Gross energy (MJ/kg) & 17.91 & 17.99 \\
\hline
\end{tabular}

a Diets 2 and 4 contained $0.15 \mathrm{~g} / \mathrm{kg}$ of an enzyme complex (Roxazyme G commercialized by DSM) that contained $800 \mathrm{U}$ of endo-1,4- $\beta$-cellulase, $1800 \mathrm{U}$ of endo-1,3(4)- $\beta$-D-glucanase and $2600 \mathrm{U}$ of endo-1,4- $\beta$-xylanase per kg of product.

${ }^{\mathrm{b}}$ Mineral and vitamin mixture supplied per kilogram of diet-vitamin A: 15,000 IU; vitamin D3: 2000 IU; vitamin E: $20 \mathrm{IU}$; vitamin C: $200 \mathrm{mg}$; thiamine: $1.5 \mathrm{mg}$; riboflavin: $5 \mathrm{mg}$; niacin: $30 \mathrm{mg}$; pantothenic acid: $15 \mathrm{mg}$; pyridoxine: $2.5 \mathrm{mg}$; folic acid: $0.5 \mathrm{mg}$; cobalamin: $0.03 \mathrm{mg}$; biotine: $0.08 \mathrm{mg}$; vitamin $\mathrm{K} 3$ : $1 \mathrm{mg}$; choline (chloride): $300 \mathrm{mg}$; potassium iodate: $1 \mathrm{mg}$; manganese (oxide): $30 \mathrm{mg}$; ferrous carbonate: $120 \mathrm{mg}$; zinc (oxide): $50 \mathrm{mg}$; copper sulphate: $5 \mathrm{mg}$; sodium selenite: $0.3 \mathrm{mg}$; cobalt carbonate: $0.5 \mathrm{mg}$; antioxidant (BHT): $30 \mathrm{mg}$.

c Calculated according to INRA (2002).

d Calculated from ingredients analysis (wheat, maize starch, wheat bran and maize cob).

e Calculated from Noblet et al. (1989).

The $\mathrm{pH}$ was determined by direct measurement of contents of the SI, caecum and colon using a pH meter (Metrohm 744, Herisau, Switzerland). Duplicate samples were analysed for $\mathrm{DM}$ by oven-drying at $105^{\circ} \mathrm{C}$ for $24 \mathrm{~h}$ and for ash content by incineration at $550{ }^{\circ} \mathrm{C}$ for $12 \mathrm{~h}$. Gross energy was measured with a peribol calorimeter (Parr 1261, Moline, Illinois, 
Table 2

Determined chemical composition of the fibre sources ( $\mathrm{g} / \mathrm{kg}$ as fed basis)

\begin{tabular}{lcc}
\hline Item & Wheat bran & ${\text { Maize } \text { cob }^{\mathrm{a}}}^{\mathrm{a}}$ \\
\hline Dry matter & 872.2 & 913.7 \\
Crude protein $(\mathrm{N} \times 6.25)$ & 170.8 & 57.0 \\
Fat & 28.8 & 5.6 \\
Starch & 166.5 & $0^{\mathrm{b}}$ \\
Neutral detergent fibre & 374.7 & 804.5 \\
Acid detergent fibre & 111.1 & 308.2 \\
Acid detergent lignin & 37.6 & 48.3 \\
Ash & 54.8 & 15.3 \\
\hline
\end{tabular}

a $n=4$.

b Not detected.

USA). The diets were analysed for NDF, ADF and acid detergent lignin according to the procedure of Van Soest et al. (1991). Nitrogen analysis of diets, urine and faeces were performed using the Kjeldahl method and starch analysis according to the enzymatic method of Thivend et al. (1965).

At slaughter, triplicate samples of the SCFA (acetic acid, butyric acid and propionic acid) from the contents of the SI, caecum and colon were quantified according to the methodology of Jouany (1982). The contents were diluted (10:1 proportion) in distilled water with a $1 \%(\mathrm{w} / \mathrm{w})$ solution of mercuric chloride and $5 \%(\mathrm{v} / \mathrm{v})$ orthophosphoric acid. The samples were centrifuged at $2000 \times g$ for $10 \mathrm{~min}$ and the SCFA were analysed in the supernatant by gas chromatography in a PerkinElmer (Sigma 3, St. Louis, MO, USA) chromatograph using a capillary column (Chromopack 7486, Middelburg, The Netherlands).

\subsection{Analysis of enzymatic activity}

At slaughter, $4 \mathrm{~g}$ of the caecum or colon contents from each piglet were collected and mixed with a $10 \mathrm{ml}$ phosphate buffer solution (pH 6.0) and immediately stored at $-20^{\circ} \mathrm{C}$. In order to rupture the microorganism cell membranes while avoiding the action of proteases, each sample was first subjected to two freeze-thaw cycles, with a freeze temperature of $-20{ }^{\circ} \mathrm{C}$ and a thaw temperature lower than $4{ }^{\circ} \mathrm{C}$. The samples were placed then in ice and treated with four sonication periods of $30 \mathrm{~s}$ according to Jehl et al. (1996). Subsequently, the total volume of each sample was centrifuged at $12,000 \times \mathrm{g}$ for $12 \mathrm{~min}$ at $-4{ }^{\circ} \mathrm{C}$ to allow the separation of the liquid fraction. The liquid fraction was collected in $1.5 \mathrm{ml}$ tubes and stored at $-20^{\circ} \mathrm{C}$ for future analysis.

Xylanase, cellulase and pectinase activities of the caecum and colon were determined according to the method proposed by Jehl et al. (1996) with some modifications. Briefly, the reaction of a sample of the xylanase, cellulase and pectinase extracts in a water bath at $39^{\circ} \mathrm{C}$ was done on xylane (Sigma X-0502), carboxymethylcellulose (Sigma C-5678) and citrus pectine (Sigma P-9135) substrates, respectively. The incubation periods were 0, 20 and $40 \mathrm{~min}$ for all enzymes. For each incubation period the reaction was halted with $700 \mu \mathrm{l}$ of 3.5 dinitro-salicylic acid. The released sugars, glucose, xylose and galacturonic acid were analysed in triplicate by the method described by Miller (1959) using a spectrophotometer 
(Model 2001, Hitachi, Tokyo, Japan). Readings were performed at $575 \mathrm{~nm}$ and enzyme activities were expressed as total enzyme activity (mg of sugars per hour released per gram of caecum and colon content DM).

\subsection{Statistical analysis}

Data concerning pig performance, SCFA and enzymatic activity were analysed by analysis of variance, according to a $2 \times 2$ factorial arrangement (SAS, 1991). Data on TTAD was subjected to analysis of variance according to a PROC MIX (Littell et al., 1998) design to test the effect of the fibre source, ES, experimental period and interactions. When the $F$ value was significant, means were compared by a Duncan's multiple range test. Differences were considered significant when P-values were less than 0.05 .

\section{Results}

\subsection{Pig performance, nitrogen balance and digesta traits}

Neither dietary fibre source nor ES affected pig performance (Table 3). Total tract apparent digestibility of DM and CP was not affected by dietary treatment. Enzyme supplementation improved TTAD of NDF and ADF $(\mathrm{P}<0.01)$, and the improvement was greater with $\mathrm{MC}$ than with WB. The digestibility of $\mathrm{CP}$ but not of other nutrients tended to increase $(\mathrm{P}<0.10)$ with age.

Neither fibre source nor ES altered $\mathrm{N}$ retention values, but an increase in feed intake from 35 to 42 days of age led to an increase in $\mathrm{N}$ intake $(\mathrm{P}<0.001)$ which in turn improved $\mathrm{N}$ retained and $\mathrm{N}$ absorbed (Table 3 ). Furthermore, relative weights of digestive organ contents was similar for all diets except for the digestive content of SI that was higher $(\mathrm{P}<0.01)$ for $\mathrm{MC}$ than for WB containing diets (Table 4).

\subsection{Fermentative activity and $\mathrm{pH}$ in the small intestine, caecum and colon}

Neither fibre source nor ES affected SCFA concentrations (mmol/l) in the SI (Table 5). There was a tendency $(\mathrm{P}<0.10)$ for a higher acetate:propionate and acetate:(propionate + butyrate) in the SI contents of MC than WB fed piglets. The ratios acetate:butyrate and acetate:(propionate + butyrate) in the SI increased $(\mathrm{P}<0.05)$ with $\mathrm{ES}$. Also, the amount of SCFA was lower in the SI than in the other compartments of the hindgut (data not shown).

The replacement of WB by $\mathrm{MC}$ in the diet increased $(\mathrm{P}<0.05)$ acetic acid content by $21 \%$ but decreased $(\mathrm{P}<0.05)$ butyric acid content by $29 \%$ in the caecum (Table 5). However, the total caecal concentrations of the three SCFA studied were not affected by ES or fibre source. The ratios acetate:propionate, acetate:butyrate and acetate:(propionate + butyrate) were significantly higher $(\mathrm{P}<0.05)$ in piglets fed $\mathrm{MC}$ than in piglets fed WB. The ES did not affect the concentration of the three SCFA in the caecum contents. 
Table 3

Effect of dietary fibre source (F), enzyme complex (ES) and period (P) on performance of piglets from 21 to 42 days of age and total tract apparent digestibility (TTAD) and nitrogen $(\mathrm{N})$ balance between 28 and 42 days of age

\begin{tabular}{|c|c|c|c|c|c|c|c|c|c|c|c|}
\hline \multirow[t]{2}{*}{ Item } & \multicolumn{2}{|c|}{ Wheat bran ${ }^{\mathrm{a}}$} & \multicolumn{2}{|c|}{ Maize $\operatorname{cob}^{\mathrm{a}}$} & \multicolumn{2}{|l|}{ Period $^{\mathrm{b}}$} & \multicolumn{5}{|c|}{ Probability ${ }^{\mathrm{c}}$} \\
\hline & - & + & - & + & 1 & 2 & $\mathrm{~F}$ & ES & $\mathrm{P}$ & $\mathrm{F} \times \mathrm{ES}$ & S.E.M. \\
\hline Feed intake (kg/day) & 0.341 & 0.346 & 0.328 & 0.333 & - & - & NS & NS & - & NS & 0.007 \\
\hline Feed conversion $(\mathrm{g}$ feed/g) & 1.41 & 1.41 & 1.45 & 1.39 & - & - & NS & NS & - & NS & 0.02 \\
\hline \multicolumn{12}{|l|}{ TTAD } \\
\hline Dry matter & 0.830 & 0.807 & 0.802 & 0.806 & 0.809 & 0.819 & NS & NS & NS & NS & 0.004 \\
\hline Organic matter & 0.845 & 0.825 & 0.817 & 0.823 & 0.824 & 0.836 & $\bullet$ & NS & NS & NS & 0.004 \\
\hline Crude protein & 0.767 & 0.758 & 0.742 & 0.780 & 0.774 & 0.758 & NS & NS & $\bullet$ & NS & 0.007 \\
\hline Neutral detergent fibre & 0.598 & 0.611 & 0.395 & 0.504 & 0.514 & 0.564 & $* * *$ & $* *$ & NS & $*$ & 0.018 \\
\hline Acid detergent fibre & 0.370 & 0.442 & 0.271 & 0.444 & 0.364 & 0.430 & $\bullet$ & $* * *$ & NS & $\bullet$ & 0.020 \\
\hline Gross energy & 0.820 & 0.792 & 0.790 & 0.799 & 0.797 & 0.808 & NS & NS & NS & $\bullet$ & 0.005 \\
\hline \multicolumn{12}{|l|}{$\mathrm{N}$ balance } \\
\hline $\mathrm{N}$ intake (g/day) & 4.49 & 4.57 & 4.20 & 4.31 & 3.54 & 5.24 & NS & NS & $* * *$ & NS & 0.14 \\
\hline $\mathrm{N}$ retention $(\mathrm{g} / \mathrm{g}$ of $\mathrm{N}$ intake $)$ & 0.570 & 0.557 & 0.518 & 0.586 & 52.1 & 60.8 & NS & NS & $* * *$ & NS & 0.020 \\
\hline
\end{tabular}

a With enzyme addition $(+)$ or without enzyme addition $(-)$.

b Period 1: 28-35 days of age and period 2: 35-42 days of age.

c There was no significant $\mathrm{F} \times \mathrm{P}, \mathrm{ES} \times \mathrm{P}$ and $\mathrm{F} \times \mathrm{ES} \times \mathrm{P}$ interaction for any variable measured.

d Standard error of the mean $(n=6)$

e Initial average body weight $=5.005 \mathrm{~kg}$.

- $\mathrm{P}<0.10$

${ }^{*} \mathrm{P}<0.05$.

** $\mathrm{P}<0.01$.

*** $\mathrm{P}<0.001$. 
Table 4

Effect of fibre source (F) and enzyme complex (ES) on the relative weight $(\mathrm{g} / \mathrm{kg}$ live weight) of digestive compartments in pigs at 42 days of age

\begin{tabular}{|c|c|c|c|c|c|c|c|}
\hline \multirow[t]{2}{*}{ Item } & \multicolumn{2}{|c|}{ Wheat bran ${ }^{a}$} & \multicolumn{2}{|c|}{ Maize $\operatorname{cob}^{\mathrm{a}}$} & \multicolumn{3}{|c|}{ Probability $^{b}$} \\
\hline & - & + & - & + & $\mathrm{F}$ & ES & S.E.M. ${ }^{c}$ \\
\hline \multicolumn{8}{|l|}{ Stomach } \\
\hline Total & 12.96 & 12.20 & 14.38 & 16.99 & $\bullet$ & NS & 0.91 \\
\hline Empty & 10.21 & 9.83 & 10.52 & 11.30 & - & NS & 0.26 \\
\hline \multicolumn{8}{|l|}{ Small intestine } \\
\hline Total & 70.24 & 66.33 & 70.70 & 75.12 & NS & NS & 1.55 \\
\hline Empty & 59.29 & 56.75 & 56.30 & 57.93 & NS & NS & 1.03 \\
\hline \multicolumn{8}{|l|}{ Large intestine } \\
\hline Total & 46.57 & 46.87 & 42.23 & 39.85 & NS & NS & 1.98 \\
\hline Empty & 22.90 & 21.69 & 24.36 & 20.41 & NS & NS & 1.04 \\
\hline Stomach content & 2.76 & 2.37 & 3.86 & 5.70 & NS & NS & 0.88 \\
\hline Small intestine content & 10.95 & 9.58 & 14.40 & 17.18 & $* *$ & NS & 1.05 \\
\hline Caecum content & 5.36 & 7.05 & 4.25 & 5.79 & NS & NS & 0.57 \\
\hline Colon content & 13.32 & 18.14 & 13.62 & 13.66 & NS & NS & 1.39 \\
\hline $\begin{array}{l}\text { a With enzyme additic } \\
\text { b There was no signifi } \\
\text { c Standard error of the } \\
\text { - } \mathrm{P}<0.10 \text {. } \\
{ }^{* *} \mathrm{P}<0.01 \text {. }\end{array}$ & $\begin{array}{l}\text { or with } \\
F \times E S i \\
n(n=6)\end{array}$ & $\begin{array}{l}\text { enzyme } \\
\text { action fo }\end{array}$ & $\begin{array}{l}\mathrm{n}(-) . \\
\text { ariable }\end{array}$ & ured. & & & \\
\hline
\end{tabular}

Butyric acid concentration in the colon were lower in piglets fed $\mathrm{MC}(\mathrm{P}<0.05)$ than in piglets fed WB (Table 5). Consequently, the ratio acetate:butyrate increased by $24 \%$ $(\mathrm{P}<0.05)$ in the colon of piglets fed MC. Source of fibre did not affect any of the other SCFA traits studied. The ES did not modify the concentration of acetic acid, propionic acid and total SCFA in the colon, even though there was a tendency for increased concentration (Table 5).

The $\mathrm{pH}$ of digestive contents was lower in the large intestine than in the $\mathrm{SI}(\mathrm{P}<0.001)$ (data not shown). The $\mathrm{pH}$ of the caecal contents was higher in the $\mathrm{MC}(\mathrm{P}<0.05)$ than in the WB diets (Table 5). The ES did not affect $\mathrm{pH}$ of the caecum. There was a tendency $(\mathrm{P}<0.10)$ for higher $\mathrm{pH}$ values in the colon contents of piglets fed $\mathrm{MC}$ as the major fibre source.

\subsection{Enzymatic activity in the caecum and colon}

Xylanase activity was lower $(\mathrm{P}<0.05)$ in the caecum than in the colon, but the pectinolytic and cellulolytic activities were similar (data not shown). Furthermore, the xylanolytic, pectinolytic and cellulolytic activities were higher $(\mathrm{P}<0.05)$ in the caecum of piglets fed WB than in the caecum of piglets fed MC by $77 \%, 64 \%$ and $87 \%$, respectively (Table 6). Xylanolytic and cellulolytic activities in the colon were also higher for WB than for MC diets $(\mathrm{P}<0.01)$. 
Table 5

Effect of fibre source (F) and enzyme complex (ES) on the concentration of short chain fatty acids and profile (molar proportions) and $\mathrm{pH}$ in the small intestine, caecal and colon contents at slaughter

\begin{tabular}{|c|c|c|c|c|c|c|c|c|}
\hline \multirow[t]{2}{*}{ Item } & \multicolumn{2}{|c|}{ Wheat bran ${ }^{a}$} & \multicolumn{2}{|c|}{ Maize $c o b^{a}$} & \multicolumn{4}{|c|}{ Probability $^{\mathrm{b}}$} \\
\hline & - & + & - & + & $\mathrm{F}$ & ES & $\mathrm{F} \times \mathrm{ES}$ & S.E.M. ${ }^{b}$ \\
\hline \multicolumn{9}{|l|}{ Concentration $(\mathrm{mmol} / \mathrm{l})^{\mathrm{c}}$} \\
\hline \multicolumn{9}{|l|}{ Small intestine } \\
\hline $\mathrm{C}_{2}$ & 17.05 & 22.19 & 20.12 & 13.13 & NS & NS & NS & 2.28 \\
\hline $\mathrm{C}_{3}$ & 4.03 & 3.84 & 3.28 & 2.09 & NS & NS & NS & 0.42 \\
\hline $\mathrm{C}_{4}$ & 2.48 & 2.99 & 2.52 & 1.43 & NS & NS & NS & 0.33 \\
\hline Total $\left(\mathrm{C}_{2}+\mathrm{C}_{3}+\mathrm{C}_{4}\right)$ & 23.56 & 29.02 & 25.92 & 16.66 & NS & NS & NS & 2.97 \\
\hline \multicolumn{9}{|l|}{ Caecum } \\
\hline $\mathrm{C}_{2}$ & 37.28 & 42.63 & 46.85 & 50.00 & $*$ & NS & NS & 2.02 \\
\hline $\mathrm{C}_{3}$ & 15.11 & 17.37 & 17.57 & 17.45 & \multirow{2}{*}{$\begin{array}{l}\text { NS } \\
*\end{array}$} & NS & NS & 0.60 \\
\hline $\mathrm{C}_{4}$ & 11.89 & 14.23 & 10.42 & 10.14 & & NS & NS & 0.66 \\
\hline Total $\left(\mathrm{C}_{2}+\mathrm{C}_{3}+\mathrm{C}_{4}\right)$ & 64.28 & 74.23 & 74.84 & 77.59 & NS & NS & NS & 2.87 \\
\hline \multicolumn{9}{|l|}{ Colon } \\
\hline $\mathrm{C}_{2}$ & 41.95 & 55.56 & 48.23 & 49.52 & NS & $\bullet$ & NS & 2.01 \\
\hline $\mathrm{C}_{3}$ & 12.13 & 16.87 & 14.76 & 14.62 & \multirow{2}{*}{$\underset{*}{\mathrm{NS}}$} & $\bullet$ & $\bullet$ & 0.70 \\
\hline $\mathrm{C}_{4}$ & 13.92 & 17.95 & 13.84 & 12.14 & & NS & * & 0.77 \\
\hline Total $\left(\mathrm{C}_{2}+\mathrm{C}_{3}+\mathrm{C}_{4}\right)$ & 68.00 & 90.39 & 76.82 & 76.28 & NS & $\bullet$ & $\bullet$ & 3.18 \\
\hline \multicolumn{9}{|l|}{ Molar proportions } \\
\hline \multicolumn{9}{|l|}{ Small intestine } \\
\hline $\mathrm{C}_{2} / \mathrm{C}_{3}$ & 4.64 & 6.19 & 6.21 & 6.32 & $\bullet$ & $\bullet$ & NS & 0.24 \\
\hline $\mathrm{C}_{2} / \mathrm{C}_{4}$ & 7.12 & 9.15 & 8.17 & 10.00 & \multirow{2}{*}{$\begin{array}{l}\text { NS } \\
\bullet\end{array}$} & \multirow{2}{*}{$\begin{array}{l}* \\
*\end{array}$} & NS & 0.45 \\
\hline $\mathrm{C}_{2} /\left(\mathrm{C}_{3}+\mathrm{C}_{4}\right)$ & 2.73 & 3.67 & 3.52 & 3.85 & & & NS & 0.15 \\
\hline \multicolumn{9}{|l|}{ Caecum } \\
\hline $\mathrm{C}_{2} / \mathrm{C}_{3}$ & 2.46 & 2.46 & 2.70 & 2.85 & $*$ & NS & NS & 0.07 \\
\hline $\mathrm{C}_{2} / \mathrm{C}_{4}$ & 3.20 & 3.10 & 4.62 & 4.99 & \multirow{2}{*}{$\begin{array}{l}* * * \\
* * *\end{array}$} & NS & NS & 0.22 \\
\hline $\mathrm{C}_{2} /\left(\mathrm{C}_{3}+\mathrm{C}_{4}\right)$ & 1.38 & 1.36 & 1.70 & 1.80 & & NS & NS & 0.06 \\
\hline \multicolumn{9}{|l|}{ Colon } \\
\hline $\mathrm{C}_{2} / \mathrm{C}_{3}$ & 3.73 & 3.31 & 3.31 & 3.42 & \multirow{2}{*}{$\underset{*}{\mathrm{NS}}$} & NS & NS & 0.12 \\
\hline $\mathrm{C}_{2} / \mathrm{C}_{4}$ & 3.19 & 3.07 & 3.64 & 4.13 & & NS & NS & 0.15 \\
\hline $\mathrm{C}_{2} /\left(\mathrm{C}_{3}+\mathrm{C}_{4}\right)$ & 1.72 & 1.59 & 1.73 & 1.86 & NS & NS & NS & 0.06 \\
\hline \multicolumn{9}{|l|}{$\mathrm{pH}$} \\
\hline Small intestine & 7.03 & 7.04 & 7.09 & 7.11 & \multirow{3}{*}{$\begin{array}{l}\text { NS } \\
* \\
\text { - }\end{array}$} & NS & NS & 0.03 \\
\hline Caecum & 6.05 & 5.96 & 6.37 & 6.36 & & NS & NS & 0.08 \\
\hline Colon & 6.61 & 6.47 & 6.74 & 6.78 & & NS & NS & 0.06 \\
\hline
\end{tabular}

${ }^{a}$ With enzyme addition (+) or without enzyme addition $(-)$.

b Standard error of the mean $(n=6)$.

c $\mathrm{C}_{2}$ : acetic acid; $\mathrm{C}_{3}$ : propionic acid; $\mathrm{C}_{4}$ : butyric acid.

- $\mathrm{P}<0.10$.

* $\mathrm{P}<0.05$.

*** $\mathrm{P}<0.001$. 
Table 6

The effect of the fibre source (F) and enzyme complex (ES) on total enzyme activity in the caecal and colon contents at slaughter

\begin{tabular}{|c|c|c|c|c|c|c|c|}
\hline \multirow[t]{2}{*}{ Item } & \multicolumn{2}{|c|}{ Wheat bran ${ }^{\mathrm{a}}$} & \multicolumn{2}{|c|}{ Maize $\operatorname{cob}^{\mathrm{a}}$} & \multicolumn{3}{|c|}{ Probability $^{\mathrm{b}}$} \\
\hline & - & + & - & + & $\mathrm{F}$ & $\mathrm{ES}$ & S.E.M. ${ }^{\mathrm{c}}$ \\
\hline \multicolumn{8}{|l|}{ Total activity $^{\mathrm{d}}$} \\
\hline \multicolumn{8}{|l|}{ Caecum } \\
\hline Xylanase & 35.58 & 42.26 & 17.73 & 26.27 & \multirow{3}{*}{ * } & NS & 3.31 \\
\hline Pectinase & 43.37 & 57.28 & 32.90 & 28.46 & & NS & 4.83 \\
\hline Cellulase & 12.50 & 21.03 & 9.47 & 8.48 & & NS & 1.56 \\
\hline \multicolumn{8}{|l|}{ Colon } \\
\hline Xylanase & 54.81 & 43.75 & 24.93 & 26.83 & $* *$ & NS & 4.16 \\
\hline Pectinase & 63.28 & 34.82 & 33.26 & 34.65 & \multirow{2}{*}{$\underset{* *}{\mathrm{NS}}$} & NS & 4.82 \\
\hline Cellulase & 19.19 & 14.80 & 6.95 & 7.10 & & NS & 1.46 \\
\hline $\begin{array}{l}\text { a With enzym } \\
\text { b There was } n \\
\text { c Standard err } \\
\text { d Total activit } \\
{ }^{*} \mathrm{P}<0.05 \text {. } \\
{ }^{*} \quad \mathrm{P}<0.01\end{array}$ & $\begin{array}{l}\text { tion }(+) \\
\text { ificant } \mathrm{F} \\
\text { he mear } \\
\text { ligram o }\end{array}$ & $\begin{array}{l}\text { hout en } \\
\text { interact } \\
\text { 6). } \\
\text { sugars r }\end{array}$ & $\begin{array}{l}\text { Idition } \\
\text { any vari }\end{array}$ & leasured & 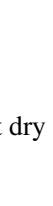 & & \\
\hline
\end{tabular}

\section{Discussion}

\subsection{Faecal apparent digestibility and nitrogen balance}

In the present study, the high digestibility of NDF and ADF fractions and the low incidence of diarrhoea during the first week post-weaning suggest a good adaptation of the piglets to the experimental diets.

Variability in digestibility of cell walls in pigs has been previously reported (Chabeauti et al., 1991). In the present study, weaned piglets fed a diet based on MC had a lower NDF digestibility than piglets fed a diet based on WB probably because of the higher proportion of cellulose, which is poorly digestible, in MC than in WB. The tendency to lower ADF digestibility in MC than WB based diets may be explained by the higher lignin content in MC, which decreases the digestibility of NSP (Stagonias and Pearce, 1985a). In addition, the higher digestibility of the NDF and ADF fractions explains the higher organic matter digestibility in WB than in MC based diets.

The effects of ES on the digestibility of the components of fibre sources is subject of debate. The ES increased the digestibility of NDF and ADF of both WB and MC diets, confirming that exogenous hemicellulases and cellulases can improve the degradation of the NSP constituents of the diet. However, ES did not improve animal performance, which agrees with Medel et al. (2002) who observed that ES in barley-based diets had no effect on piglet performance.

As previously reported (Freire et al., 2000), the improvement in $\mathrm{N}$ retention from 35 to 42 days resulted of the increased $\mathrm{N}$ intake with age which is indicative of synthesis of muscular tissue in the second and third weeks after weaning. 


\subsection{Fermentative and enzymatic activity}

The results of the present study for the total SCFA content and individual profiles in the different compartments of the GIT tract agree with previous work by Bach Knudsen et al. (1991) and Freire et al. (2000). The production of SCFA was higher in the caecum and colon than in the SI, which was expected because the digesta remains longer in the distal than in the proximal GIT and the microbial population is greater in the caecum and colon than in the SI (Simpson et al., 1999). Also, the population of Lactobacillus is higher in the SI (Hill et al., 2005) and it is known that Lactobacillus produce more lactic acid than SCFA (Jin et al., 2000), in agreement with our results.

In the current work, the ratio acetate:(propionate + butyrate) was higher in the SI than in the caecum and colon suggesting a colonization by acetic acid producing bacteria of the proximal compartments of the GIT. Acetate is the major end product of the fermentation of pectin (Zacharias et al., 2004), and the results of the current study suggest that the degradation of easy fermentable substances, like pectins, starts before entering the large intestine. The larger variety of microbes in the large intestine (Pryde et al., 1999) may explain the increased production of propionate and butyrate in this organ.

Xylanase activity and NDF digestibility were higher in WB than in the MC diets indicative of higher fermentation of arabinoxylans in the WB diet. Probably the fermentation of the arabinoxylan present in WB resulted in an increased production of butyrate (Bach Knudsen et al., 1993) that was detected in the caecum and colon of piglets fed WB. This observation agrees with Stagonias and Pearce (1985b) who found a higher proportion of butyric acid in the proximal colon of pigs fed WB compared to other fibre sources such as lupin hulls, MC or lucern stems.

Butyrate promotes the intestinal colonization by Lactobacillus in detriment of the Escherichia coli bacteria colonization (Jin et al., 2000). Thus, the health of the colon epithelium might be improved by SCFA production, butyrate in particular. In the present study, the production of butyrate in the caecum and colon of piglets was higher with WB than with MC suggesting that WB is more advantageous for intestinal health than MC.

The ES increased acetate content in the SI as compared to other SCFA. Probably, the hemicellulolytic activity in the ES diets degrades the main substrates available for the bacteria that produce propionate and butyrate and there is a large population of acetateforming bacteria in the SI, which may explain the higher content of acetate in comparison to the other SCFA. Furthermore, ES did not affect enzyme activity in the caecum and colon of pigs but modified the molar proportions of SCFA in the SI, suggesting an effect of ES in digestion.

In the current study, $\mathrm{pH}$ was negatively correlated with SCFA production in the caecum of piglets fed MC and in the colon of piglets fed WB. In addition, SCFA production was higher and $\mathrm{pH}$ was lower in the large intestine than in the SI.

Xylanase and cellulase activities in both caecum and colon were higher in piglets fed WB diets than in piglets fed MC. Probably, higher amounts of microbial enzymes able to degrade NSP were present in the caecum and colon of pigs fed WB which is confirmed by the higher digestibility of NDF and ADF observed for these diets. 


\section{Conclusions}

The digestibility of neutral detergent fibre and acid detergent fibre and the xylanase and cellulase activities in the caecum and colon were higher with wheat bran then with maize cob diets. In addition, wheat bran increased the concentration of butyric acid in the caecum and colon contents. Also, enzyme supplementation increased the apparent faecal digestibility of neutral detergent fibre and acid detergent fibre and the molar proportions of acetic acid in the small intestine in both wheat bran and maize cob diets.

\section{Acknowledgments}

The authors wish to thank Fundação para a Ciência e Tecnologia (POCTI/CVT/ 37545/2001) for providing financial support and Dr. Luís Gama for advice on statistical analysis.

\section{References}

Bach Knudsen, K.E., 2001. The nutritional significance of “dietary fibre” analysis. Anim. Feed Sci. Technol. 90, 3-20.

Bach Knudsen, K.E., Aman, P., Eggum, B.O., 1991. Gastrointestinal implications in pigs of wheat and oat fractions. 2. Microbial activity in the gastrointestinal tract. Br. J. Nutr. 65, 233-248.

Bach Knudsen, K.E., Jensen, B.B., Hansen, I., 1993. Oat bran but not a $\beta$-glucan-enriched oat fraction enhances butyrate production in the large intestine of pigs. J. Nutr. 123, 1235-1247.

Baidoo, S.K., Liu, Y.G., Yungblut, D., 1998. Effect of microbial enzyme supplementation on energy, amino acid digestibility and performance of pig fed hulless barley for swine. Can. J. Anim. Sci. 78, 202-210.

Chabeauti, E., Noblet, J., Carré, B., 1991. Digestion of plant cell walls from four different sources in growing pigs. Anim. Feed Sci. Technol. 32, 207-213.

Corring, T., Juste, C., Lhoste, E.F., 1989. Nutritional regulation of pancreatic and biliary secretions. Nutr. Res. Rev. 2, 161-180.

Freire, J.P.B., Guerreiro, A.J.G., Cunha, L.F., Aumaitre, A., 2000. Effect of dietary fibre source on total tract digestibility, caecum volatile fatty acids and digestive transit time in the weaned piglet. Anim. Feed Sci. Technol. 87, 71-83.

Gill, B.P., Mellange, J., Rookle, L.A., 2000. Growth performance and apparent nutrient digestibility in weaned piglets offered wheat-, barley- or sugar-beet-pulp-based diets supplemented with food enzymes. Anim. Sci. $70,107-118$.

Hill, J.E., Hemmingsen, S.M., Goldade, B.G., Dumonceaux, T.J., Klassesn, J., Zijlstra, R.T., Goh, S.H., Van Kessel, A.G., 2005. Comparison of ileum microflora of pigs fed corn-, wheat-, or barley-based diets by chaperonin-60 sequencing and quantitative PCR. Appl. Environ. Microbiol. 71, 867-875.

INRA, 2002. Tables de composition et de valeur nutritive des matières premières destinées aux animaux d'élevage. INRA Editions et AFZ, Paris, France.

Jehl, N., Gidenne, T., Le Roux, J.F., 1996. Measurements of the bacterial fibrolytic activity in the caecum and in the soft faeces of the rabbit. In: Lebas, F. (Ed.), Proceedings of the Sixth World Rabbit Congress, vol. 1. Toulouse, France, July 9-12, 1996. Ass. Fr. Cuniculture, Lempdes, France, pp. 199-203.

Jin, L., Marquardt, R.R., Baidoo, S.K., 2000. Inhibition of enterotoxigenic Escherichia coli K88, K99 and 987P by the Lactobacillus isolates from porcine intestine. J. Sci. Food Agric. 80, 619-624.

Jouany, J.P., 1982. Volatile fatty acid and alcohol determination in digestive contents, silage juices, bacterial cultures and anaerobic fermentor contents. Sci. Aliments 2, 131-144. 
Konstantinov, S.R., Favier, C.F., Zhu, W.Y., Williams, B.A., Klub, J., Suoffrant, W.-B., de Vos, W.M., Akkermans, A.D.L., Smidt, H., 2004. Microbial diversity studies of the porcine gastrointestinal ecosystem during weaning transition. Anim. Res. 53, 317-324.

Li, S., Sauer, W.C., Huang, S.X., Gabert, V.M., 1996. Effect of beta-glucanase supplementation to hulless barley or wheat-soybean meal diets on the digestibility of energy, protein, beta-glucans and amino acids in young pigs. J. Anim. Sci. 74, 1649-1659.

Littell, R.C., Henry, P.R., Ammerman, C.B., 1998. Statistical analysis of repeated measures data using SAS procedures. J. Anim. Sci. 76, 1216-1231.

Lizardo, R., Peiniau, J., Aumaitre, A., 1997. Inclusion of sugar-beet pulp and change of protein source in the diet of the weaned piglet and their effects on digestive performance and enzymatic activities. Anim. Feed Sci. Technol. 66, 1-14.

Medel, P., Baucells, F., Gracia, M.I., de Blas, C., Mateos, G.G., 2002. Processing of barley and enzyme supplementation in diets for young pigs. Anim. Feed Sci. Technol. 95, 113-122.

Miller, G.L., 1959. The use on dinitro-salicylic reagent for determination of reducing sugar. Anal. Chem. 31, 426-428.

Montagne, L., Pluske, J.R., Hampson, D.J., 2003. A review of interactions between dietary fibre and the intestinal mucosa, and their consequences on digestive health in young non-ruminant animals. Anim. Feed Sci. Technol. 108, 95-117.

Noblet, J., Fortune, H., Dubois, S., Henry, Y., 1989. Nouvelles bases d'estimation des teneurs en energie digestible, metabolisable et nette de aliments pour le porc. Institut National de la Recherche Agronomique, Paris, p. 106.

Pellerin, P., Gosselin, M., Lepoutre, J.P., Samain, E., Debeire, P., 1991. Enzymic production of oligosaccharides from corncob xylan. Enzyme Microb. Technol. 13, 617-621.

Pryde, S.E., Richardson, A.J., Stewart, C.S., Flint, H.J., 1999. Molecular analysis of the microbial diversity present in the colonic wall, colonic lumen, and caecal lumen of a pig. Appl. Environ. Microbiol. 65, 5372-5377.

SAS, 1991. SAS Systems for Linear Models, Third ed. SAS Institute Inc., Cary, NC, USA.

Simpson, J.M., McCracken, V.J., White, B.A., Gaskins, H.R., Machie, R.I., 1999. Application of denaturant gradient gel electrophoresis for the analysis of the porcine gastrointestinal microbiota. J. Microbiol. Methods 36, 167-179.

Stagonias, G., Pearce, G.R., 1985a. The digestion of fibre by pigs. 1. The effects of amount and type of fibre on apparent digestibility, nitrogen balance and rate of passage. Br. J. Nutr. 53, 513-530.

Stagonias, G., Pearce, G.R., 1985b. The digestion of fibre by pigs. 2. Volatile fatty acid concentrations in large intestine digesta. Br. J. Nutr. 53, 531-536.

Thivend, P., Mercier, C., Guilbot, A., 1965. Dosage de l'amidon dans les milieux complexes. Ann. Biol. Anim. Biochem. Biophys. 5, 513-526.

Van Soest, P.J., Robertson, J.B., Lewis, B.A., 1991. Carbohydrate methodology, metabolism and nutritional implications in dairy cattle. J. Dairy Sci. 74, 3583-3597.

Wang, J.F., Zhu, Y.H., Li, D.F., Wang, M., Jensen, B.B., 2004. Effect of type and level of dietary fibre and starch on ileal and faecal microbial activity and short-chain fatty acid concentrations in growing pigs. Anim. Sci. 78, 109-117.

Zacharias, B., Kerler, A., Drochner, W., 2004. The influence of 5\% and 10\% dietary apple pectin on parameters of fermentation in faeces and caecal digesta of weaning pigs. Arch. Anim. Nutr. 58, 149-156. 